\title{
Liter per Milligram per Hour
}

National Cancer Institute

\section{Source}

National Cancer Institute. Liter per Milligram per Hour. NCI Thesaurus. Code C85673.

Liters per milligram per hour. 